\title{
Influence of the North Atlantic Oscillation on air pollution transport
}

\author{
T. Christoudias ${ }^{1}$, A. Pozzer ${ }^{2,3},{ }^{*}$, and J. Lelieveld ${ }^{2,3,4}$ \\ ${ }^{1}$ Computation-based Science and Technology Research Center, The Cyprus Institute, Nicosia, Cyprus \\ ${ }^{2}$ Energy, Environment and Water Research Center, The Cyprus Institute, Nicosia, Cyprus \\ ${ }^{3}$ Air Chemistry Department, Max Planck Institute of Chemistry, Mainz, Germany \\ ${ }^{4}$ King Saud University, Riyadh, Saudi Arabia \\ *now at: Abdus Salam International Center for Theoretical Physics, Earth System Physics, Trieste, Italy \\ Correspondence to: T. Christoudias (christoudias@cyi.ac.cy)
}

Received: 27 July 2011 - Published in Atmos. Chem. Phys. Discuss.: 19 September 2011

Revised: 23 December 2011 - Accepted: 9 January 2012 - Published: 19 January 2012

\begin{abstract}
We examined the influence of the North Atlantic Oscillation (NAO) on the atmospheric dispersion of pollution by computing the emission, transport and removal of idealized insoluble gaseous and water-soluble aerosol tracers, tagged by the continent of origin. We simulated a period of $50 \mathrm{yr}$ (1960-2010), using the ECHAM5/MESSy1 atmospheric chemistry (EMAC) general circulation model. The model accounts for anthropogenic, biogenic and biomass burning sources, removal of trace gases through $\mathrm{OH}$ oxidation, and precipitation, sedimentation and deposition of aerosols. The model is shown to reproduce the observed spatial features of the NAO, moisture transports and precipitation. During high NAO phase seasons the axis of maximum westerly North American trace gas transports extends relatively far to the north and east over Europe. The NAO phase is significantly correlated with North American insoluble gas and soluble aerosol tracer concentrations over the northwestern Atlantic Ocean and across northern Europe, and with European trace gases and aerosols over Africa and north of the Arctic circle. We find a strong anti-correlation between the phase of the NAO and European pollutant gas concentration over western and central Europe.
\end{abstract}

\section{Introduction}

The North Atlantic Oscillation (NAO) is a major recurring large-scale pattern of interannual variability in the atmospheric circulation of the Northern Hemisphere. The NAO is manifested by swings in the meridional atmospheric pressure difference between the sub-polar and sub-tropical Atlantic Ocean, most prominently during boreal winter, and is associated with changes in the mean wind speed and di- rection (Hurrell et al., 2003). In periods of higher than average pressure difference (positive NAO phase), when both the tropical high and polar low pressure features are relatively stronger, the north-south gradient produces an enhanced zonal (west to east) flow. When both the tropical high and polar low pressure features are relatively weak (negative NAO phase), the synoptic scale flow has a reduced zonal component. Thus, influences on the interannual variability of hemispheric-scale pollution transport pathways related to the NAO are expected.

The study of the NAO impact on pollution transport is further motivated by results from several previous relevant analyses. Moulin et al. (1997) report the modulation of African dust transport by the NAO and suggest that it is likely that the NAO also affects the distribution of other aerosols. Dentener et al. (2010) reference a number of studies indicating the potential impact of the NAO on pollution transport. $\mathrm{Li}$ et al. (2002) imply that the NAO can be used to forecast transatlantic transport of North American pollution to Europe based on a $5 \mathrm{yr}$ simulation of tropospheric chemistry evaluating North Atlantic coastal station measurements. They find that the strength of the prevailing westerlies favors transport close to the surface. Creilson et al. (2003) also find that the NAO aids the transport of anthropogenic pollution from North America to Europe by influencing the westerly winds across the North Atlantic. Eckhardt et al. (2003) have studied the control that the NAO exerts over pathways of pollution transport towards the Arctic simulating fixed lifetime passive tracers over $15 \mathrm{yr}$ and found that there is a strong relation between the NAO and surface concentrations of carbon monoxide (CO) in the Arctic, most pronounced during winter and spring. They also note that European pollution can build-up in the Arctic, with faster poleward transport during

Published by Copernicus Publications on behalf of the European Geosciences Union. 
the positive phase of the NAO. In the present paper we study the emission and transport of tagged idealised tracers, with the characteristics of carbon monoxide (CO) and aerosols in the atmosphere, simulated over a $50 \mathrm{yr}$ period to include several positive and negative NAO phases in order to deduce robust patterns, using the ECHAM5/MESSy1 Atmospheric Chemistry (EMAC) climate model.

$\mathrm{CO}$ is a sensitive tracer for long-range transport of pollution as it is directly emitted by combustion sources and has a lifetime of 1-3 months in the atmosphere. Anthropogenic $\mathrm{CO}$ emissions are distributed similarly to those of many gaseous and particulate anthropogenic pollutants. To obtain a realistic description of tracer lifetime and abundance in the atmosphere we include a removal mechanism through oxidation by the hydroxyl $(\mathrm{OH})$ radical, the main oxidant controlling the oxidizing capacity of the atmosphere. The $\mathrm{OH}$ radical is highly reactive and oxidises $\mathrm{CO}$ to form carbon dioxide $\mathrm{CO}_{2}$.

Aerosols are a major component of atmospheric pollution and have important effects on human health (Huntingford et al., 2007), the environment and hydrological cycle (Ramanathan et al., 2001) and climate (Isaksen et al., 2009). To study the impact of the NAO on tropospheric aerosol pollution we simulated the emissions and transport of idealised water-soluble aerosols. To decouple from the effects of initial distributions and allow for the direct comparison of the NAO effects on aerosol transport with those on trace gases, and to highlight differences in removal mechanisms, identical emission patterns are used for gases and aerosols. Aerosols in the present model setup are not chemically active but are affected by sedimentation and dry and wet deposition processes and are predominantly removed from the atmosphere by precipitation.

We briefly describe the model in Sect. 2, including the emissions of tagged tracers and removal mechanisms (Sect. 2.1). The simulation of the spatial structure and temporal evolution of the NAO is presented in Sect. 2.2. Seasonal averages for simulated fields are presented throughout the paper. The analysis of our results regarding the influence of the NAO on the intercontinental transport of tracer gases and aerosols is discussed in Sect. 3. The summary and conclusions are given in Sect. 4.

\section{Model simulation}

The EMAC model is a numerical chemistry and climate simulation system that includes sub-models describing tropospheric and middle atmosphere processes and their interaction with oceans, land and human influences (Jöckel et al., 2005). It uses the first version of the Modular Earth Submodel System (MESSy1) to link multi-institutional computer codes. The core atmospheric model is the 5th generation European Centre Hamburg general circulation model (ECHAM5, Roeckner et al., 2006).
For the present study we applied EMAC version 1.9 (based on ECHAM5 version 5.3) on the T42L19 resolution, i.e. with a spherical spectral truncation of T42 (corresponding to a quadratic gaussian grid of approximately 2.8 by 2.8 degrees in latitude and longitude) with 19 vertical hybrid pressure levels up to $10 \mathrm{hPa}$. The sea surface temperature and sea ice distribution for AMIP II simulations (Taylor et al., 2000) between the years 1960-2010 were used as boundary conditions. The applied model setup comprised the submodels MECCA1 (Sander et al., 2005) for tropospheric and stratospheric chemistry, though highly simplified, RAD4ALL for radiation and heating processes, CLOUD for cloud cover and micro-physics processes including precipitation, and CONVECT for the vertical transports of trace species associated with convection. The DRYDEP (Kerkweg et al., 2006) and SCAV (Tost et al., 2006, 2007) submodels are used to simulate aerosol dry and wet deposition processes, respectively.

Large-scale stratiform and small-scale convective precipitation are the dominant mechanisms for the removal of watersoluble chemically inert aerosols in the model. Our simulation is shown to reproduce the basic features of the average distribution of precipitation observed by Adler et al. (2003, Global Precipitation Climatology Project (GPCP)) in the region of interest between 1979-2004 in Fig. 1. In the domain $20^{\circ}-80^{\circ} \mathrm{N}$ and $90^{\circ} \mathrm{W}-40^{\circ} \mathrm{E}$, average precipitation in excess of $10 \mathrm{~cm} \mathrm{month}^{-1}$ follows a southwest to northeast pattern over the Atlantic Ocean with maximum values of the order of $15-20 \mathrm{~cm} \mathrm{month}^{-1}$ occurring off the eastern coast of the United States. Finer scale features over the southeastern United States and the western Scandinavian coast are also reproduced. The model overestimates precipitation over some parts of southern Europe close to the Mediterranean Sea though with an extent and magnitude that is expected to have limited influence on the results.

\subsection{Emissions}

The emission scheme of Pozzer et al. (2012) was adapted for the purposes of this study. Anthropogenic fossil fuel and biofuel $\mathrm{CO}$ emissions were simulated based on the global inventory prepared in the framework of the CIRCE project by the Emission Database for Global Atmospheric Research (EDGAR) of the EC-Joint Research Center Ispra, Climate Change Unit (Doering et al., 2009a,b). Emissions by international aviation were calculated using a technology based emission factor approach (Eyers et al., 2004). Production of CO from international shipping is based on the QUANTIFY project (Hoor et al., 2009). The vertical distribution of anthropogenic emissions, is based on experience from the European Monitoring and Evaluation Programme (EMEP) model (Simpson et al., 2003), and is described in Pozzer et al. (2009). Biogenic emissions have been compiled following Guenther et al. (1995) and are prescribed offline in the model. The contribution to emissions by biomass burning 


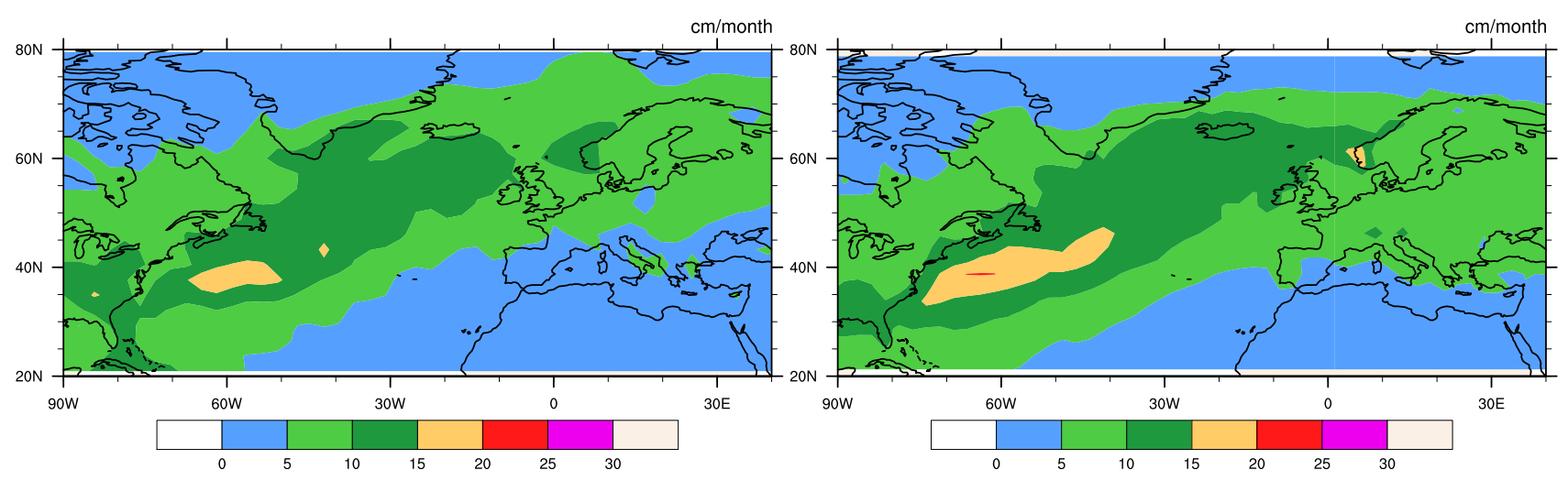

Fig. 1. Observed (Adler et al., 2003, Global Precipitation Climatology Project (GPCP)) (left) and modeled (right) average precipitation (in $\mathrm{cm} \mathrm{month}^{-1}$ ) between 1979-2004.

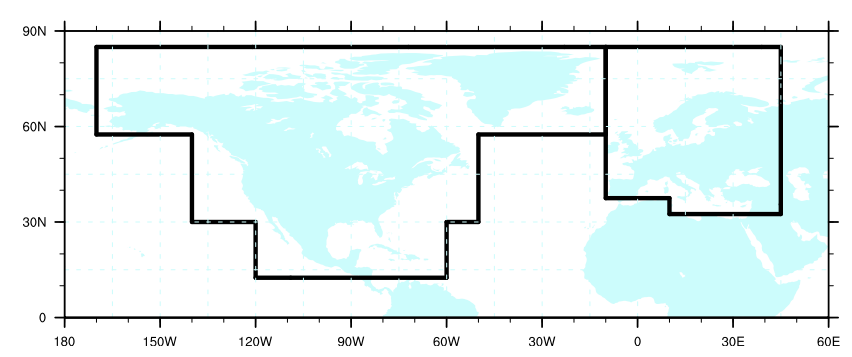

Fig. 2. Depiction of the regions used for the computation of emissions.

was included using the Global Fire Emissions Database (GFED version 3, van der Werf et al., 2010).

We use the base year 2005 with a monthly temporal resolution climatology for all emissions, except for biomass burning for which a 10 yr monthly average climatology (20002009 ) is used. The CO tracer is tagged by the regions of emission, i.e. from North America and Europe (see Fig. 2). Emissions from eastern Russia are very small and are not included in our definition of Europe. We do not account for the atmospheric chemical production of CO $\left(\sim 1000 \mathrm{Tg} \mathrm{yr}^{-1}\right.$, Seinfeld and Pandis, 1997).

Loss of the tagged $\mathrm{CO}$ tracers is computed using the monthly atmospheric concentration of $\mathrm{OH}$ from the fullchemistry simulation in Pozzer et al. (2012). CO is removed from the atmosphere via the mechanism:

$\mathrm{CO}+\mathrm{OH} \rightarrow \mathrm{CO}_{2}+\mathrm{HO}_{2}$

In the absence of a full chemistry mechanism in the model, which would account for the recycling of $\mathrm{OH}$ (Lelieveld et al., 2004), we apply the following simplification:

$\mathrm{CO}+\mathrm{OH} \rightarrow \mathrm{CO}_{2}+\mathrm{OH}$

This ensures a realistic spatio-temporal representation of the lifetime of $\mathrm{CO}$ in the atmosphere while preventing that $\mathrm{OH}$ is depleted by the reaction with $\mathrm{CO}$.
Aerosols are emitted using regional emission patterns and concentrations identical to CO. This facilitates the direct comparison of the effects of the NAO on the transport of trace gas and aerosol pollutants and their removal mechanisms. Water-soluble aerosols with a standard lognormal distribution of mean radius $0.5 \mu \mathrm{m}(\sigma=1.0)$ and a molar mass of $96.076 \mathrm{~g} \mathrm{~mol}^{-1}$ (equal to sulfate) with a Henry coefficient equal to $1.0 \mathrm{moll}^{-1} \mathrm{~atm}^{-1}$ and a density of $1841.0 \mathrm{~kg} \mathrm{~m}^{-3}$ are used.

\subsection{North Atlantic Oscillation as represented by EMAC}

The EMAC model, forced by the realistic AMIP II sea surface temperature and ice coverage boundary conditions, generates its own meteorology and climate variability, which cannot be identical to the true observed variability during the period 1960-2010. Nevertheless, the characteristics of the generated NAO variations (spatial structure and temporal variability) are found to be similar to observations.

There is no unique way to define the spatial structure and temporal evolution of the NAO. We applied several common approaches to evaluate our model. The NAO primary centers of action are identified in maps of $500 \mathrm{hPa}$ geopotential height distributions as regions of maximum anti-correlation over the North Atlantic (Fig. 3). The $500 \mathrm{hPa}$ height time series at a reference point $\left(65^{\circ} \mathrm{N}, 30^{\circ} \mathrm{W}\right)$ is correlated with the corresponding time series at all points, revealing a northsouth dipole, with one centre over the North Atlantic close to the Arctic and the other over the subtropical Atlantic, as expected.

The NAO signal is not readily apparent in the empirically determined orthogonal function (EOF) spatial pattern of the observed Northern Hemisphere (NH) winter $500 \mathrm{hPa}$ height, but rather rotated (linearly combined) EOFs (Hurrell et al., 2003) have to be used. However, the NAO signal is apparent in the EOF spatial pattern at surface level. The spatial pattern reflected in the leading EOF of the North Atlantic sector $\left(20^{\circ}-80^{\circ} \mathrm{N}, 90^{\circ} \mathrm{W}-40^{\circ} \mathrm{E}\right)$ seasonal (3-month average) sea 


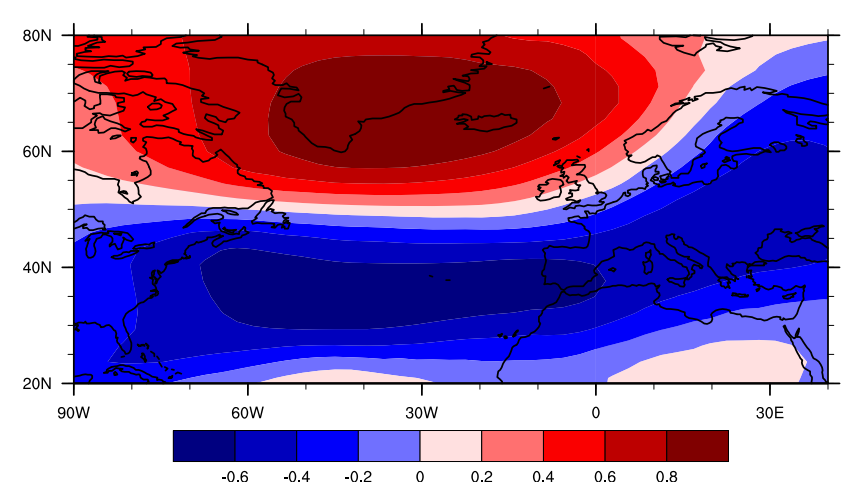

Fig. 3. One-point correlation map of model $500 \mathrm{hPa}$ geopotential height for boreal winter (December-February) over the period 1960-2010. The reference point is $65^{\circ} \mathrm{N}, 30^{\circ} \mathrm{W}$.

level pressure (SLP) anomalies field (Fig. 4, top) explains $38 \%$ of the total variance and compares well with the NAO pattern observed by Hurrell (2010). In this approach, the $\mathrm{NAO}$ is identified from the spatially and temporally mutually orthogonal eigenvectors of the cross-covariance matrix of time varying values of SLP. Again, a north-south pressure difference dipole over the Atlantic Ocean in the northern hemisphere is apparent. By regressing the SLP anomalies on the principal component time series the pattern is obtained in terms of pressure amplitude, with maximum departure of the field at the centre of the poles of the order of $\pm 3 \mathrm{hPa}$, in good agreement with the equivalent analysis of observations by Hurrell (2010).

The normalised principal component time series of the leading EOF is correlated to the model seasonal NAO index (determined as the difference in normalised sea level pressure between a stationary point at Ponta Delgada, Azores, and a stationary point in Stykkishólmur/Reykjavík, Iceland; adapted from Hurrell, 1995) with a correlation coefficient of 0.93 (Fig. 4, bottom). This result, similar to observations, further indicates that the leading EOF captures the temporal variation also described by the NAO index and allows to interchange the use of the pressure difference index and the EOF time series to diagnose the temporal variation of the pattern.

\section{Results}

\subsection{Vertically integrated transports}

The vertically integrated tracer transport vector is defined as

$\boldsymbol{Q}=\frac{1}{g} \int_{0}^{p_{\mathrm{S}}} q \boldsymbol{u} d p$

where $q$ is the tracer mole ratio in $\mathrm{mol} \mathrm{mol}^{-1}, \boldsymbol{u}$ the horizontal vector wind, and $p$ is pressure; $p_{\mathrm{S}}$ denotes surface pressure and $g$ represents gravity. This variable is analogous
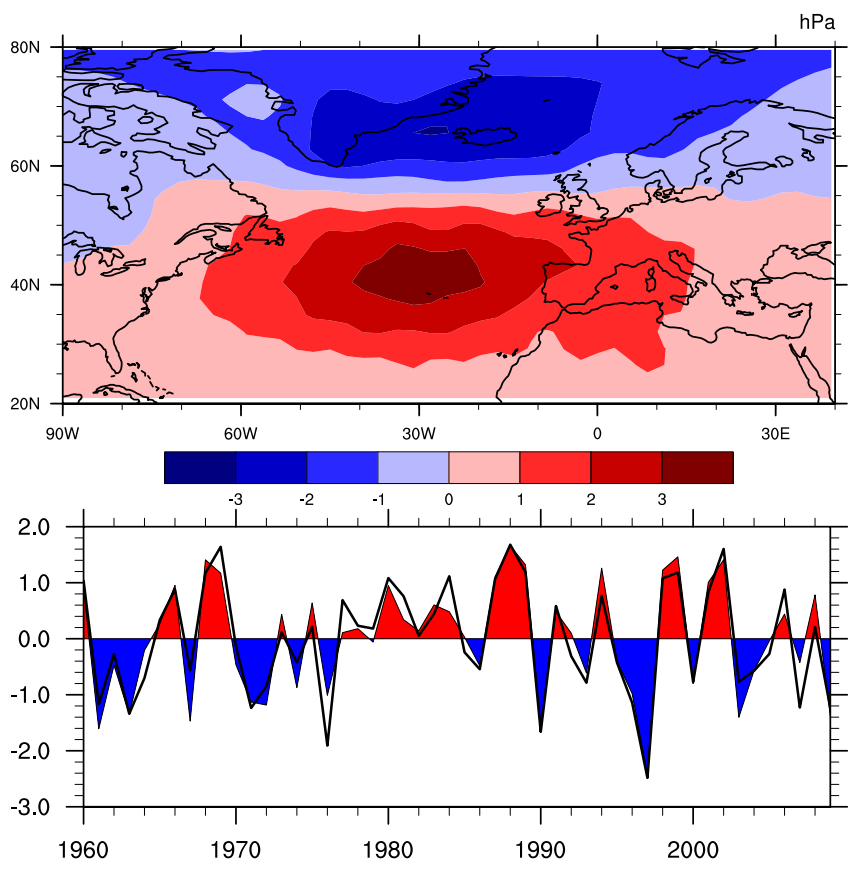

Fig. 4. Top: leading empirical orthogonal function (EOF1) of the winter (December-February) mean sea level pressure (SLP) anomalies in the North Atlantic sector $\left(20^{\circ}-80^{\circ} \mathrm{N}, 90^{\circ} \mathrm{W}-40^{\circ} \mathrm{E}\right)$ which explains $38 \%$ of the total variance. The pattern is displayed in terms of amplitude ( $\mathrm{hPa}$ ), obtained by regressing the SLP anomalies on the principal component time series. Bottom: principal component time series (red, blue) of the leading EOF plotted with the modeled NAO index (black) based on the normalised SLP difference between Ponta Delgada, Azores, and Stykkishólmur/Reykjavík, Iceland. The correlation coefficient is 0.93 .

to the vertically integrated moisture transport (see Fig. 5), which was used to test our model simulation against the observations compiled by Hurrell (1995). During seasons of low or negative NAO index moisture transport over the Atlantic Ocean follows a westerly zonal path with maximum vector magnitudes occurring in the western part of the domain, stretching across the mid-Atlantic. During seasons of high NAO index the axis of maximum moisture transport shifts to a more southwest-to-northeast orientation over the Atlantic and extends farther to the northern and eastern part of Europe.

We calculated the temporal average of $\boldsymbol{Q}$ for all winters with high $(>1)$ and with low or negative $(<0)$ EOF principal component time series values. In total, 10 high and 23 low or negative EOF time series seasonal averages enter the composites. The axis of maximum westerly North American $\mathrm{CO}$ tracer transport extends much farther to the north and east, over northwestern Europe and Scandinavia, during seasonal composites with high NAO phase when compared to seasonal composites with low or negative NAO phase. This is indicated by vector plots of the vertically integrated total tracer transports (Fig. 6, top). The equivalent analysis for the 

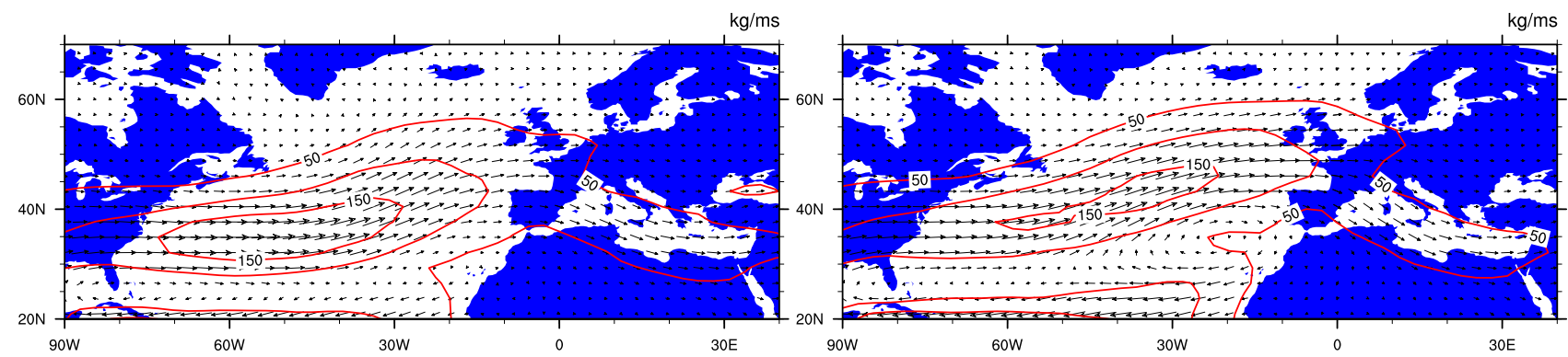

Fig. 5. Average vertically integrated moisture (in $\mathrm{kg} \mathrm{kg}^{-1}$ ) transport vectors for winters with low or negative (left) and high (right) EOF time series. Red contour lines correspond to vector magnitudes.
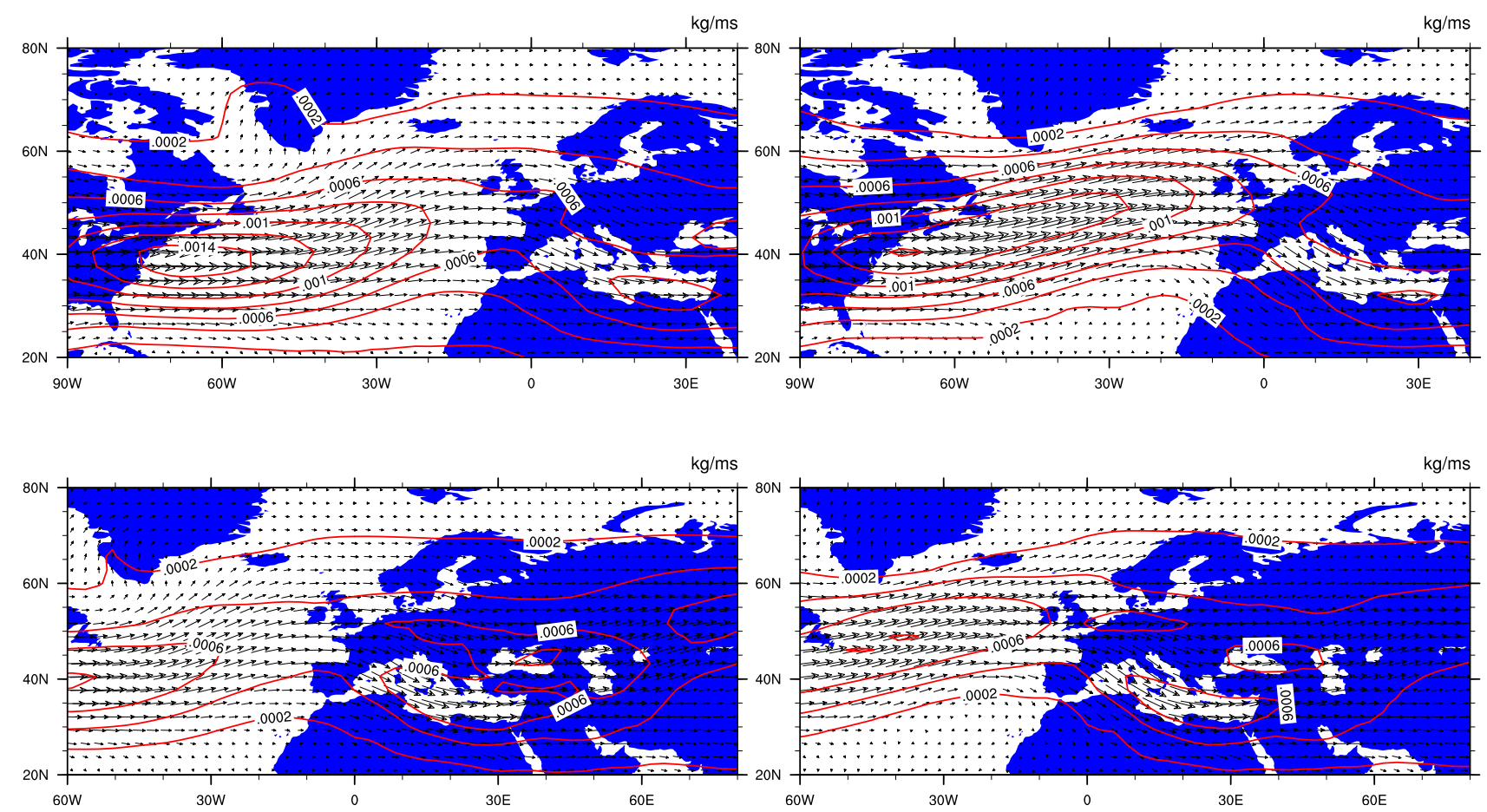

Fig. 6. Average vertically integrated $\mathrm{CO}$ tracer (in $\mathrm{mol} \mathrm{mol}^{-1}$ ) transport vectors with North American origin (top) and European origin (bottom) for winters with low or negative (left) and high (right) EOF time series. Contour lines correspond to vector magnitudes.

$\mathrm{CO}$ tracer originating in Europe shows similar results over the Atlantic Ocean and a relative increase in transport over mainland Europe towards the East (Fig. 6, bottom).

\subsection{NAO index - tracer concentration correlation}

After identifying the principal component time variation, we examine the relation of the NAO with tracer concentrations. The correlation of the principal component time series with gas and aerosol concentration anomalies has been calculated for the model surface level and for the meridional vertical profile at $30^{\circ} \mathrm{W}$. The results can be seen in Figs. 7 and 8 for the gaseous tracers and aerosols originating in the North American and European regions, respectively.
The principal component time series, and hence the phase of the NAO, is significantly correlated to North American $\mathrm{CO}$ tracer concentration anomalies over the northwestern Atlantic Ocean, and is anti-correlated to CO tracer concentrations over the tropical Atlantic Ocean (Fig. 7) close to the surface. For soluble aerosol species originating in North America the effect is stronger, with higher significantly positive correlations extending much farther over the North Atlantic across northwestern Europe. The patterns extend vertically, spanning the free troposphere with strong correlations around $60^{\circ} \mathrm{N}$ and anti-correlations at sub-tropical latitudes, being most pronounced for the soluble aerosol species. The anti-correlation for soluble aerosols extends to the equatorial region across Africa. 

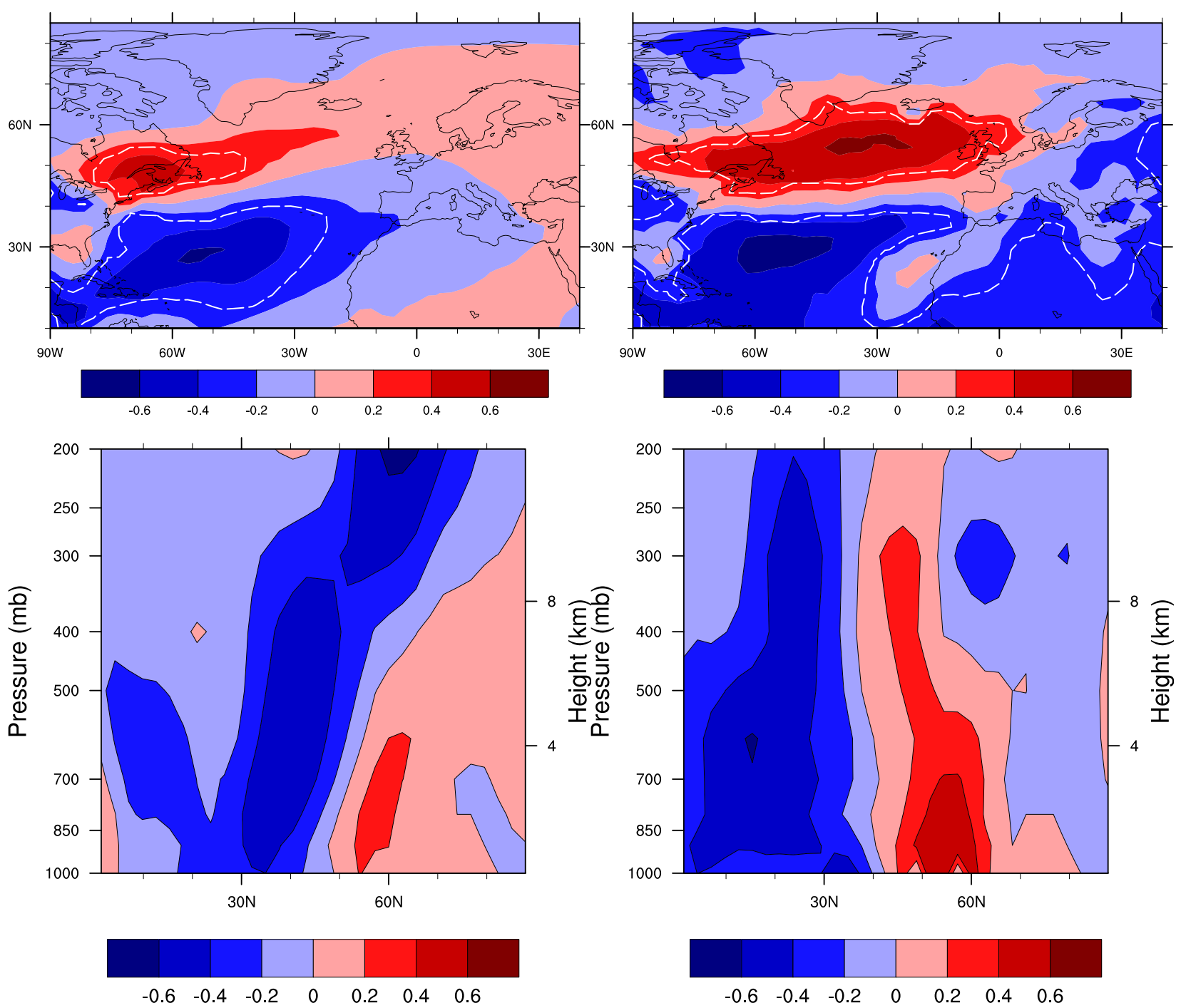

Fig. 7. Correlation of winter (December-February) seasonal surface concentration anomalies (top) and meridional vertical profiles at $30^{\circ} \mathrm{W}$ (bottom) with the principal component of the EOF time series of SLP in the North Atlantic sector for gaseous tracers (left) and soluble aerosols (right) emitted from North America. White dashed contour lines indicate the local $95 \%$ level of significance.

During conditions associated with the negative NAO phase, transport is directed more strongly to the east and southeast as opposed to the more northeastward flow under positively high NAO phase. This is suggested by the anti-correlation of the $\mathrm{CO}$ tracer over the western parts of Africa. The correlation changes to positive values over the eastern parts of Africa. This is probably related to enhanced transport of North American CO during high NAO along an anticyclonic path first leading towards northern Europe and then southwards to eastern Europe and finally onwards to Africa. A stronger Azores High during the positive NAO phase leads to enhanced north to south transport over Eastern Europe. This pathway can potentially have a different effect on the water-soluble tracer due to efficient washout along this path, leading to reduced soluble aerosol concentrations during high NAO.
The phase of the NAO is significantly correlated to European tracer concentration anomalies at the surface over high latitudes, within the Arctic circle, and over the Middle East, and anti-correlated over the eastern Atlantic Ocean (Fig. 8). The anti-correlation over northern Europe for the water-soluble aerosols may be explained by the effect of the $\mathrm{NAO}$ on the spatial distribution of precipitation, the main removal mechanism in the model. Swings in the NAO index are reflected in the transport and convergence of atmospheric moisture. High NAO index winters exhibit drier conditions over much of central and southern Europe, the Mediterranean and parts of the Middle East, whereas more than average precipitation falls over Scandinavia and Iceland (Hurrell, 1995).

Also, during the positive NAO phase, both the Icelandic Low and the Azores High are more pronounced. This leads to a stronger separation of the flow over Europe, with enhanced 

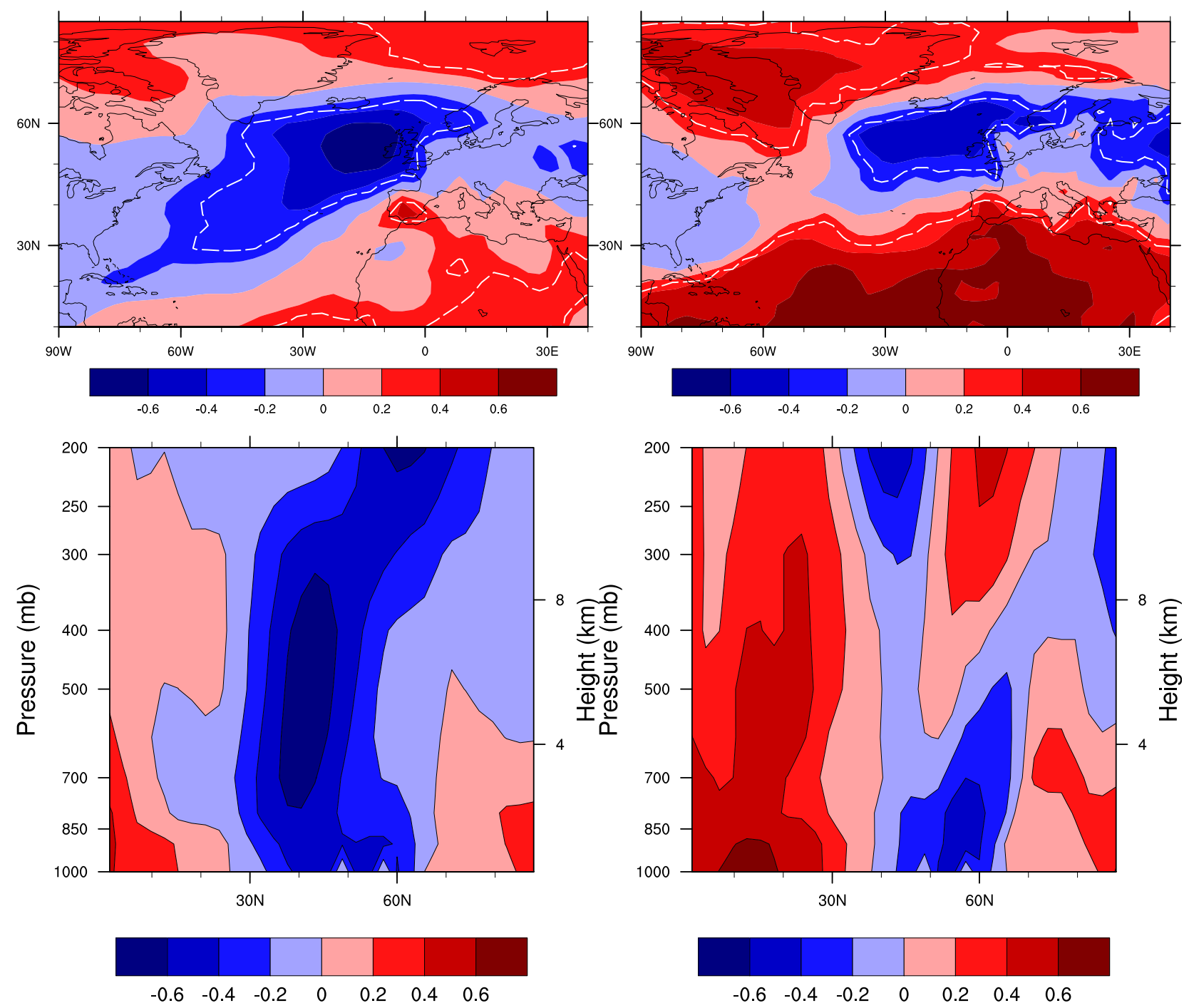

Fig. 8. Correlation of winter (December-February) seasonal surface concentration anomalies (top) and meridional vertical profiles at $30^{\circ} \mathrm{W}$ (bottom) with the principal component of the EOF time series of SLP in the North Atlantic sector for gaseous tracers (left) and soluble aerosols (right) emitted from Europe. White dashed contour lines indicate the local $95 \%$ level of significance.

northward transport over the northern parts of Europe and enhanced southward transport over the southern parts. The European tracer is thus relatively depleted over central Europe, as it is either carried towards southern Europe and northern Africa (creating positive anomalies there) under the influence of the Azores High, or to the Arctic under the influence of the Icelandic low.

During conditions associated with the negative NAO phase, conversely, the air is more stagnant over Central Europe allowing European pollutants to accumulate. The strong negative anomaly over the western Atlantic is thus simply an effect of reduced direct outflow of European air pollution to this region due to the enhanced north-south pressure gradient and associated westerlies. In the vertical profiles, a strong anti-correlation centred at $500 \mathrm{hPa}$, with a vertical extent from the surface to the tropopause region, is most apparent for the gaseous CO tracer, along with a weak surface correlation both at high and low latitudes. Interestingly, the gaseous tracer anomalies are highly anti-correlated with the NAO in the lowermost stratosphere at $\sim 200 \mathrm{hPa}$, which could be further investigated with an EMAC model version of the middle atmosphere (Jöckel et al., 2006). There are marked differences with the vertical profile for water-soluble aerosols, with a relatively strong correlation at tropical latitudes, which we attribute to the influence of the NAO phase and amplitude on the locations of high moisture and precipitation. It should be emphasized that aerosol concentrations in the upper troposphere are low, and even though the correlations are significant, the practical implications are of limited relevance. 


\section{Conclusions}

A $50 \mathrm{yr}$ tracer transport simulation with the EMAC model was used to study the influence of the NAO on the distribution of atmospheric pollution. Regionally tagged tracers of carbon monoxide and water-soluble aerosols were emitted using a fixed emission climatology, taking into account anthropogenic (fossil fuel, biofuel, aviation and shipping) sources, natural sources and biomass burning. Removal mechanisms were included based on oxidation of $\mathrm{CO}$ by the $\mathrm{OH}$ radical and sedimentation and dry and wet deposition of aerosols. The model simulation of the boreal winter NAO spatial pattern was tested against observations using common and established approaches. Good agreement with results reported from observations was obtained throughout.

The NAO phase is related to pollution transport from North America towards Europe, mostly in the free troposphere. The NAO is associated with stronger-than-average westerlies across the middle latitudes of the Atlantic that transport air pollution from North America towards Europe and Northwestern Africa, similar to moisture transport.

The NAO exerts a clear influence on the atmospheric distribution of aerosol pollution. The NAO phase strongly affects the magnitude and direction of moisture transport, including water-soluble aerosols emitted in North America and Europe, over the Atlantic Ocean. The NAO also affects the location and extent of the spatial pattern of precipitation. During high NAO index periods, drier than average conditions occur over much of central and southern Europe, the Mediterranean and parts of the Middle East, whereas more precipitation than average falls over a region from Iceland through Scandinavia (Hurrell, 1995). As precipitation is the main mode of removal of water-soluble aerosols from the atmosphere, the distribution of particulate pollutants, especially from Europe, is indirectly influenced by the NAO. The response of the aerosols is relatively strong, as they are influenced both by NAO-related transport and wet deposition anomalies, whereas $\mathrm{CO}$ is unaffected by precipitation.

Hurrell (1995) concludes that decadal variability in the NAO has become especially pronounced since 1950 , with unprecedented strongly positive index values since 1980. If this trend persists, e.g. associated with climate change (Intergovernmental Panel on Climate Change, 2007), it can be expected that in the future the NAO will have a growing influence on intercontinental pollution transport between North America and Europe and from Europe towards the Arctic.

Acknowledgements. We are most grateful for the comments, constructive criticism and very useful suggestions by the anonymous referees. The research leading to these results has received funding from the European Research Council under the European Union's Seventh Framework Programme (FP7/2007-2013)/ERC grant agreement no. 226144.

Edited by: B. Vogel

\section{References}

Adler, R., Huffman, G., Chang, A., Ferraro, R., Xie, P., Janowiaks, J., Rudolf, B., Schneider, U., Curtis, S., Bolvin, D., Gruber, A., and Susskind, P. A.: The Version 2 Global Precipitation Climatology Project (GPCP) Monthly Precipitation Analysis (1979Present), J. Hydrometeorol., 4, 1147-1167, 2003.

Creilson, J. K., Fishman, J., and Wozniak, A. E.: Intercontinental transport of tropospheric ozone: a study of its seasonal variability across the North Atlantic utilizing tropospheric ozone residuals and its relationship to the North Atlantic Oscillation, Atmos. Chem. Phys., 3, 2053-2066, doi:10.5194/acp-3-2053-2003, 2003.

Dentener, F., Keating, T., and Akimoto, H. (Eds.): Hemispheric Transport of Air Pollution, United Nations, ISBN: 978-92-1117043-6, 2010.

Doering, U., Monni, S., Pagliari, V., Orlandini, L., van Aardenne, and SanMartin, F.: CIRCE report D8.1.1 " Emission inventory for the past period 1990-2005 on $0.1 \times 0.1$ grid ", Tech. rep., Project FP6: 6.3, No. 036961, 2009a.

Doering, U., van Aardenne, J., Monni, S., Pagliari, V., Orlandini, L., and SanMartin, F.: CIRCE report D8.1.2 - Evaluation emission database 1990-2005, Tech. rep., Project FP6: 6.3, No. 036961 , 2009b.

Eckhardt, S., Stohl, A., Beirle, S., Spichtinger, N., James, P., Forster, C., Junker, C., Wagner, T., Platt, U., and Jennings, S. G.: The North Atlantic Oscillation controls air pollution transport to the Arctic, Atmos. Chem. Phys., 3, 1769-1778, doi:10.5194/acp3-1769-2003, 2003.

Eyers, C. J., Addleton, D., Atkinson, K., Broomhead, M., Christou, R., Elliff, T., Falk, R., I., G., Lee, D. C. M., Michot, S., Middel, J., Newton, P., P., N., Plohr, M., Raper, D., and Stanciou, N.: AERO2k, Global Aviation Emissions Inventories for 2002 and 2025, Tech. rep., QINETIQ/04/01113, 2004.

Guenther, A., Hewitt, C. N., Erickson, D., Fall, R., Geron, C., Graedel, T., Harley, P., Klinger, L., Lerdau, M., McKay, W. A., Pierce, T., Scholes, B., Steinbrecher, R., Tallamraju, R., Taylor, J., and Zimmerman, P.: A global model of natural volatile organic compound emissions, J. Geophys. Res., 100, 8873-8892, 1995.

Hoor, P., Borken-Kleefeld, J., Caro, D., Dessens, O., Endresen, O., Gauss, M., Grewe, V., Hauglustaine, D., Isaksen, I. S. A., Jöckel, P., Lelieveld, J., Myhre, G., Meijer, E., Olivie, D., Prather, M., Schnadt Poberaj, C., Shine, K. P., Staehelin, J., Tang, Q., van Aardenne, J., van Velthoven, P., and Sausen, R.: The impact of traffic emissions on atmospheric ozone and $\mathrm{OH}$ : results from QUANTIFY, Atmos. Chem. Phys., 9, 3113-3136, doi:10.5194/acp-9-3113-2009, 2009.

Huntingford, C., Hemming, D., Gash, J., Gedney, N., and Nuttall, P.: Impact of climate change on health: what is required of climate modellers?, Transactions of the Royal Society of Tropical Medicine and Hygiene, 101, 97-103, doi:10.1016/j.trstmh.2006.11.001, 2007.

Hurrell, J. W.: Decadal Trends in the North Atlantic Oscillation: Regional Temperatures and Precipitation, Science, 269, 676679, 1995.

Hurrell, J. W.: CGD's Climate Analysis Section: Detailed Descriptions of Climate Indices, http://www.cgd.ucar.edu/cas/jhurrell/ indices.info.html\#naopcd\%jf, 2010.

Hurrell, J. W., Kushnir, Y., Ottersen, G., and Visbeck, M.: An 
Overview of the North Atlantic Oscillation, in: The North Atlantic Oscillation: Climatic Significance and Environmental Impact, edited by: Hurrell, J. W., Kushnir, Y., Ottersen, G., and Visbeck, M., 1-35, Geophysical Monograph, 2003.

Intergovernmental Panel on Climate Change: Climate Change 2007: The physical Science Basis, in: The Properties of Gases and Liquids, 3rd edition, edited by: Solomon, S., Qin, D., Manning, M., Chen, Z., Marquis, M., Averyt, K. B., Tignor, M., and Miller, H. L., IPCC Fourth Assassement report (AR4), 2007.

Isaksen, I. S. A., Granier, C., Myhre, G., Berntsen, T. K., Dalsøren, S. B., Gauss, M., Klimont, Z., Benestad, R., Bousquet, P., Collins, W., Cox, T., Eyring, V., Fowler, D., Fuzzi, S., Jöckel, P., Laj, P., Lohmann, U., Maione, M., Monks, P., Prevot, A. S. H., Raes, F., Richter, A., Rognerud, B., Schulz, M., Shindell, D., Stevenson, D. S., Storelvmo, T., Wang, W.-C., van Weele, M., Wild, M., and Wuebbles D.: Atmospheric composition change: Climate-Chemistry interactions, Atmos. Environ., 43, 5138-5192, 2009.

Jöckel, P., Sander, R., Kerkweg, A., Tost, H., and Lelieveld, J.: Technical Note: The Modular Earth Submodel System (MESSy) - a new approach towards Earth System Modeling, Atmos. Chem. Phys., 5, 433-444, doi:10.5194/acp-5-433-2005, 2005.

Jöckel, P., Tost, H., Pozzer, A., Brühl, C., Buchholz, J., Ganzeveld, L., Hoor, P., Kerkweg, A., Lawrence, M. G., Sander, R., Steil, B., Stiller, G., Tanarhte, M., Taraborrelli, D., van Aardenne, J., and Lelieveld, J.: The atmospheric chemistry general circulation model ECHAM5/MESSy1: consistent simulation of ozone from the surface to the mesosphere, Atmos. Chem. Phys., 6, 50675104, doi:10.5194/acp-6-5067-2006, 2006.

Kerkweg, A., Buchholz, J., Ganzeveld, L., Pozzer, A., Tost, H., and Jöckel, P.: Technical Note: An implementation of the dry removal processes DRY DEPosition and SEDImentation in the Modular Earth Submodel System (MESSy), Atmos. Chem. Phys., 6, 4617-4632, doi:10.5194/acp-6-4617-2006, 2006.

Lelieveld, J., Dentener, F. J., Peters, W., and Krol, M. C.: On the role of hydroxyl radicals in the self-cleansing capacity of the troposphere, Atmos. Chem. Phys., 4, 2337-2344, doi:10.5194/acp4-2337-2004, 2004.

Li, Q., Jacob, D. J., Bey, I., Palmer, P. I., Duncan, B. N., Field, B. D., Martin, R. V., Fiore, A. M., Yantosca, R. M., Parrish, D. D., Simmonds, P. G., and Oltmans, S. J.: Transatlantic transport of pollution and its effects on surface ozone in Europe and North America, J. Geophys. Res., 107, ACH 4, doi:10.1029/2001Jd001422, 2002.

Moulin, C., Lambert, C. E., Dulac, F., and Dayan, U.: Control of atmospheric export of dust from North Africa by the North Atlantic Oscillation, Nature, 387, 691-694, 1997.
Pozzer, A., Jöckel, P., and Van Aardenne, J.: The influence of the vertical distribution of emissions on tropospheric chemistry, Atmos. Chem. Phys., 9, 9417-9432, doi:10.5194/acp-9-9417-2009, 2009.

Pozzer, A., de Meij, A., Pringle, K., Tost, H., Doering, U. M., van Aardenne, J., and Lelieveld, J.: Aerosol simulation with high resolution emissions with the EMAC model, Atmos. Chem. Phys., in press, 2012.

Ramanathan, V., Crutzen, P., Kiehl, J., and Rosenfeld, D.: Aerosols, climate, and the hydrological cycle, Science, 294, 2119-2124, 2001.

Roeckner, E., Brokopf, R., Esch, M., Giorgetta, M., Hagemann, S., Kornblueh, L., Manzini, E., Schlese, U., and Schulzweida, U.: Sensitivity of simulated climate to horizontal and vertical resolution in the ECHAM5 atmosphere model, J. Clim., 19, 37713791, 2006.

Sander, R., Kerkweg, A., Jöckel, P., and Lelieveld, J.: Technical note: The new comprehensive atmospheric chemistry module MECCA, Atmos. Chem. Phys., 5, 445-450, doi:10.5194/acp-5445-2005, 2005.

Seinfeld, J. H. and Pandis, S.: Atmospheric Chemistry and Physics: From Air Pollution to Climate Change, Wiley-Interscience, 1997.

Simpson, D., Fagerli, H., Jonson, J., Tsyro, S., Wind, P., and Tuovinen, J.-P.: Unified EMEP Model Description., Tech. rep., Norwegian Meteorological Institute, 2003.

Taylor, K., Williamson, D., and Zwiers, F.: The sea surface temperature and sea ice concentration boundary conditions for AMIP II simulations; PCMDI Report, Tech. Rep. 60, Program for Climate Model Diagnosis and Intercomparison, 2000.

Tost, H., Jöckel, P., Kerkweg, A., Sander, R., and Lelieveld, J.: Technical note: A new comprehensive SCAVenging submodel for global atmospheric chemistry modelling, Atmos. Chem. Phys., 6, 565-574, doi:10.5194/acp-6-565-2006, 2006.

Tost, H., Jöckel, P., Kerkweg, A., Pozzer, A., Sander, R., and Lelieveld, J.: Global cloud and precipitation chemistry and wet deposition: tropospheric model simulations with ECHAM5/MESSy1, Atmos. Chem. Phys., 7, 2733-2757, doi:10.5194/acp-7-2733-2007, 2007.

van der Werf, G. R., Randerson, J. T., Giglio, L., Collatz, G. J., Mu, M., Kasibhatla, P. S., Morton, D. C., DeFries, R. S., Jin, Y., and van Leeuwen, T. T.: Global fire emissions and the contribution of deforestation, savanna, forest, agricultural, and peat fires (19972009), Atmos. Chem. Phys., 10, 11707-11735, doi:10.5194/acp10-11707-2010, 2010. 